\title{
PENERAPAN METODE SIMPLE ADDITIVE WEIGHTING (SAW) UNTUK MENENTUKAN KINERJA KARYAWAN TERBAIK PADA PT.ARMORINDO ARTHA
}

\author{
Hiysam Ash Shiddigie ${ }^{1)}$, Ita Novita ${ }^{2)}$ \\ ${ }^{1}$ Sistem Informasi, Fakultas Teknologi Informasi, Universitas Budi Luhur \\ ${ }^{1,2} \mathrm{Jl}$. Raya Ciledug, Petukangan Utara, Kebayoran Lama, Jakarta Selatan 12260 \\ E-mail : hiysamashshiddigie@gmail.com ${ }^{1)}$, ita.novita@budiluhur.ac.id ${ }^{2)}$
}

\begin{abstract}
Abstrak
Karyawan merupakan salah satu aset perusahaan yang harus dikelola dengan baik, karyawan bertugas untuk merencanakan dan melaksanakan proses bekerja pada suatu perusahaan. PT. ARMORINDO ARTHA merupakan sebuah perusahaan swasta yang bergerak di bidang Cash In Transit dan Cash Management Service. Cash In Transit adalah pengangkutan uang tunai dari suatu titik ke titik lainnya atau pengisian uang tunai ke dalam mesin ATM, sedangkan Cash Management Service adalah pemeliharaan mesin ATM, penggantian kertas transaksi, pengambilan kartu ATM yang tertelan dan sebagainya. Untuk meningkatkan suatu perusahaan maka dilakukan evaluasi terhadap kinerja karyawan. Masalah yang terjadi pada evaluasi kinerja karyawan adalah proses pengambilan keputusan kinerja karyawan kurang akurat, karena belom terdapat metode perangkingan. Penelitian ini bertujuan untuk mengembangkan sebuah sistem penunjang keputusan karyawan terbaik menggunakan metode Simple Additive Weighting (SAW). Penelitian ini di uji dengan 5 data alternatif dengan hasil urutan pertama 0.9788, urutan kedua 0.9683 dan ketiga 0.9268. Sistem penunjang keputusan penentuan kinerja karyawan terbaik yang dibuat dapat membantu dalam melakukan penilaian kinerja karyawan lebih tepat.
\end{abstract}

Kata kunci: Sistem Penunjang Keputusan, Simple Additive Weighting (SAW), penilaian kinerja karyawan.

\section{PENDAHULUAN}

Pertumbuhan teknologi informasi pada zaman sekarang sangat masif. Maka dari itu menuntut suatu perusahaan untuk tetap bertahan menghadapi persaingan dengan melihat kinerja karyawan yang memiliki kompetensi yang tinggi. Dalam hal ini perusahaan harus melihat kinerja karyawan untuk menjadi penentu keberhasilan suatu perusahaan dalam mencapai tujuan perusahaan tersebut. Oleh karena itu perusahaan penting untuk memperhatikan karyawan yang mempunyai pengaruh tinggi untuk bekerja dalam tim dan membantu untuk kemajuan perusahaan. Maka dibutuhkan penilaian kinerja karyawan untuk melanjutkan tujuan perusahaan antara lain kelangsungan hidup perusahaan, pertumbuhan dan keuntungan.

PT. ARMORINDO ARTHA merupakan sebuah perusahaan swasta yang bergerak dibidang Cash In Transit dan Cash Management Service. Cash In Transit adalah pengangkutan uang tunai dari suatu titik ke titik lainnya atau pengisian uang tunai ke dalam mesin ATM, sedangkan Cash Management Service adalah pemeliharaan mesin ATM, penggatian kertas transaksi, pengambilan kartu ATM yang tertelan dan sebagainya. Maka dalam hal ini perusahaan membutuhkan karyawan yang berkinerja baik untuk meningkatkan perusahaan.

Maka dibutuhkan sistem penunjang keputusan kinerja karyawan di PT.Armorindo Artha. Metode yang akan digunakan untuk membangun sistem penunjang keputusan ini adalah metode Simple Additive Weighting (SAW). Alasan peneliti menggunakan metode Simple Additive Weighting $(S A W)$ karena lebih fleksibel, dapat memecahkan persoalan yang kompleks dan melakukan pembelajaran berdasarkan pengetahuan dan pengalaman manusia dalam memecahkan suatu masalah dari setiap kriteria berbeda dan metode $S A W$ dapat menghasilkan nilai terbesar yang akan dipilih menjadi alternatif terbaik. Dengan dibangunnya sistem penunjang keputusan ini, diharapkan dapat membantu Direktur Utama PT.Armorindo Artha memecahkan permasalahan terkait penilaian kinerja karyawan.

Kendala yang terjadi dalam proses penilaian kinerja karyawan adalah belum menghasilkan hasil yang maksimal dalam pengambilan keputusan, terutama jika terdapat beberapa karyawan yang memiliki kemampuan yang tidak jauh berbeda, maka hanya menilai berdasarkan perkiraan. Dalam mengambil keputusan saat proses penilaian kinerja karyawan, ada beberapa kriteria dasar yang menjadi acuan antara lain : absensi, kualitas kerja, kerjasama, dan kedisiplinan. 


\section{METODE PENELITIAN}

\subsection{Sistem Penunjang Keputusan}

"Sistem penunjang keputusan ialah suatu langkah untuk menentukan pemungutan hasil ketetapan”. Sistem penunjang keputusan memakai data, memberikan tampilan pengguna dengan mudah, dan bisa mengintegrasikan ide pemilik keputusan. Pembuatan keputusan merupakan fungsi utama seorang manajer atau administrator.

Sistem Penunjang Keputusan (SPK) atau Decision Support System (DSS) bertujuan dalam menjadikan alat pembantu kepada pemilik keputusan untuk memperbesar kapabilitas mereka. DSS ditujukan kepada para pengambil keputusan yang membutuhkan penilaian atau pada keputusan yang tidak sistematis. Ada beberapa komponen Sistem Penunjang[1].

1) Subsistem Manajemen Data (Data Management Subsystem)

2) Subsistem Manajemen Model (Model Management Subsystem)

3) Subsistem Antar Muka Pengguna (User Interface Subsystem)

4) Subsistem Manajemen Pengetahuan (Knowledge Management Subsystem)

Berikut komponen-komponen DSS yang digunakan ada management data, management model, user interface dan knowledge management. Yang terdapat pada Gambar 1.

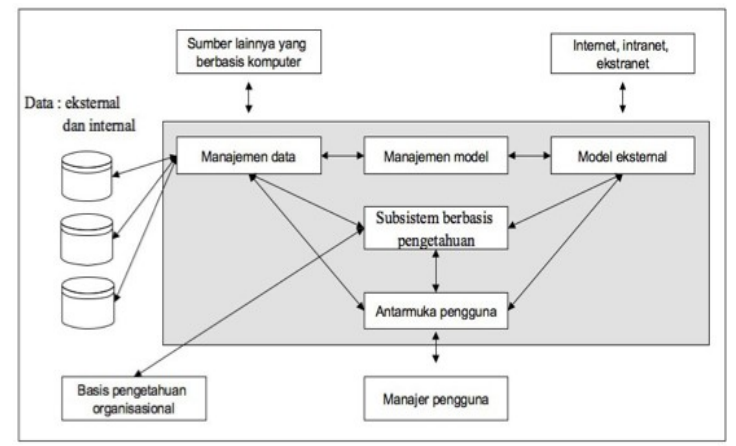

Gambar 1. Komponen Decision Support System

\subsection{Metode Simple Additive Weighting}

Metode Simple Additive Weighting (SAW) kerap diketahui dengan sebutan metode penambahan yang bernilai. Rancangan landasan metode $S A W$ ialah untuk mengetahui penambahan bernilai dari tingkat kinerja di setiap alternatif serta semua atribut. Metode SAW memerlukan langkah-langkah normalisasi kerangka keputusan (X) ke suatu skala yang dapat dianalogikan pada setiap rating alternatif yang ada[2].

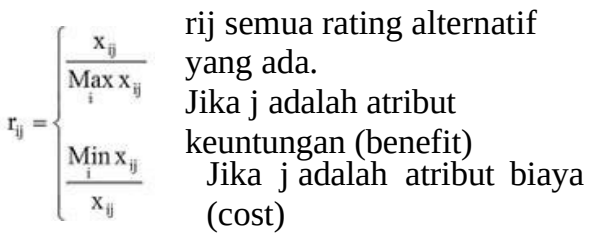

rij sebagai rating kinerja ternormalisasi pada setiap alternatif Ai pada atribut $\mathrm{Cj} ; \mathrm{i}=1,2, \ldots, \mathrm{m}$ dan $\mathrm{j}=1,2, \ldots$, n. Langkah pengerjaan memakai metode SAW:

a. Memastikan kriteria yang dipakai untuk pengambilan keputusan.

b. Memastikan kriteria-kriteria yang akan digunakan dalam pengambilan keputusan, yaitu $\mathrm{Cj}$.

c. Memastikan nilai bobot dari setiap kriteria yang digunakan.

Tabel 1 Kriteria dan Bobot

\begin{tabular}{|l|r|}
\hline \multicolumn{1}{|c|}{ Kriteria } & Bobot \\
\hline C1 & $60 \%$ \\
\hline C2 & $13.3 \%$ \\
\hline C3 & $13.3 \%$ \\
\hline C4 & $13.3 \%$ \\
\hline \multicolumn{2}{|l|}{} \\
\hline
\end{tabular}

d. Menentukan rating kecocokan nilai alternatif pada setiap kriteria.

e. Untuk menentukan matriks keputusan berdasarkan kriteria (Ci), lalu membuat normalisasi matriks berdasarkan persamaan yang sesuai dengan jenis atribut (atribut keuntungan serta atribut biaya) sehingga menghasilkan matriks ternormalisasi R.

f. Menentukan nilai preferensi untuk setiap alternatif (Vi):

$$
\mathrm{V}_{\mathrm{i}}=\sum_{\mathrm{j}=1}^{\mathrm{n}} \mathrm{w}_{\mathrm{j}} \mathrm{r}_{\mathrm{ij}}
$$

$\mathrm{Vi}=$ Hasil untuk setiap alternatif

wj = Angka dari bobot per kriteria

rij = Angka dari rating kinerja ternormalisasi

Untuk hasil akhir didapat pada langkahlangkah perangkingan yaitu penjumlahan dari perkalian matriks ternormalisasi $\mathrm{R}$ pada vector bobot sehingga menghasilkan nilai tertinggi yang dipilih sebagai alternatif terbaik $\left(A_{i}\right)$ sebagai solusi.

\subsection{Penelitian Sebelumnya}

Nurul Chafid dan Nanang Harianto merancang sistem pendukung keputusan penilaian karyawan dan melakukan perangkingan kinerja karyawan dengan grade terbaik menggunakan metode Simple 
Additive Weighting (SAW) dengan kriteria penilaian yang ditetapkan yaitu absensi, pengetahuan tentang produk, kemampuan berkomunikasi, pendidikan terakhir, dan jiwa kepemimpinan[3].

Ades Galih Anto, Hindayati Mustafidah dan Aman Suyadi membangun sistem pendukung keputusan penilaian kinerja karyawan, menggunakan metode Simple Additive Weighting (SAW) dengan kriteria penilaian yang ditetapkan yaitu penilaian umum, tingkat kehadiran, tingkat pendidikan, pengembangan diri, dan unsur penunjang[4].

Handri Murdianto, Dyna Marisa Khairina dan Heliza Rahmania Hatta membuat sistem pendukung keputusan pemilihan karyawan terbaik menggunakan metode Simple Additive Weighting (SAW) dengan kriteria penilaian yang ditetapkan yaitu pengetahuan pekerjaan, inisiatif pekerjaan, produktifitas pekerjaan, komunikasi, kerjasama, tanggung jawab, dan kehadiran [5].

\subsection{Tahapan Penelitian}

Pada riset yang dilakukan penulis memakai metode pengumpulan data, informasi, dan materi yang saling berhubungan pada persoalan masalah di PT. ARMORINDO ARTHA yaitu:

\section{1) Metode Pengumpulan Data}

a. Observasi

Dilakukan dengan cara melihat langsung pada tempat riset yang berhubungan dengan pengambilan penilaian kinerja karyawan, dan juga untuk memilih karyawan yang berkinerja baik pada riset yang dilakukan ini.

b. Wawancara

Proses dimana penulis mengumpulkan data dengan melakukan tatap muka secara langsung dan memberi pertanyaan yang berhubungan tentang penilaian kinerja karyawan, serta pemilihan karyawan yang berkinerja dengan baik oleh Supervisor sebagai pihak yang mempunyai wewenang untuk menyelenggarakannya. Hal yang didapat dari dilakukannya wawancara oleh penulis adalah mendapatkan proses bisnis dan kriteria serta bobot dalam melakukan penilaian kinerja karyawan maupun pemilihan karyawan yang berkinerja dengan baik.

c.Analisa Dokumen

Dalam menganalisa dokumen berjalan, agar dapat menghasilkan informasi yang bisa membantu penulis untuk menentukan sesuai sistem yang akan dibuat, perlu menentukan metode yang akan digunakan untuk penelitian.

d. Studi Pustaka

Pada studi pustaka ini penulis melakukan pencarian jurnal dan membaca jurnal atau e- book serta refrensi yang berhubungan pada teori penilaian kinerja karyawan, teori pemilihan karyawan yang berkinerja dengan baik, teori Sistem Penunjang Keputusan, teori Simple Additive Weighting (SAW) dan teoriteori lain yang berhubungan dengan pembuatan sistem penunjangkeputusan.

e.Kuesioner

Pada proses kuesioner ini penulis melakukan pertanyaan terhadap monitoring, selaku yang memberi penilaian karyawan berdasarkan kriteria yang ditentukan. Sesuai hasil yang didapat pada kuesioner maka diperoleh perhitungan pada penilaian kinerja karyawan dan pemilihan kinerja karyawan dengan baik.

\section{2) Instrumentasi}

Penelitian yang dilakukan oleh penulis ialah menggunakan teknik wawancara dan menyebarkan kuesioner sebagai instrumentasi. Teknik wawancara dilakukan kepada Supervisor PT. Armorindo Artha untuk memperoleh informasi tentang bagaimana proses penilaian kinerja karyawan dan pemilihan karyawan yang berkinerja dengan baik. Pada teknik kuesioner digunakan sebagai intrumentasi yang disebarkan kepada responden ahli, maka didapatkan pernyataan yang digunakan dalam mengukur apa yang telah ditemukan dalam teknik wawancara.

\section{3) Teknik Analisa Data}

Dalam melakukan teknik analisa data maka penulis memakai analisa deskriptif dan menggunakan metode Simple Additive Weighting (SAW). Analisa deskriptif digunakan untuk menyajikan rangkuman yang didapat pada hasil survei. Metode Simple Additive Weighting (SAW) dilakukan untuk menghasilkan perangkingan karyawan yang diurutkan dari nilai tertinggi hingga ke nilai terendah agar dapat memperoleh hasil untuk menentukan karyawan berkinerja baik. Alasan menggunakan metode ini ialah mudah dimengerti, lebih fleksibel, dapat memecahkan persoalan yang kompleks, melakukan pembelajaran berdasarkan pengetahuan dan pengalaman manusia dalam memecahkan suatu masalah.

\section{HASIL DAN PEMBAHASAN}

\subsection{Proses Berjalan}

Pada proses berjalan dalam pengambilan keputusan terdapat 4 aktor yaitu supervisor (SPV), leader, manager dan karyawan. Proses bisnis berjalan akan ditampilkan dalam activity diagram di Gambar 2. 


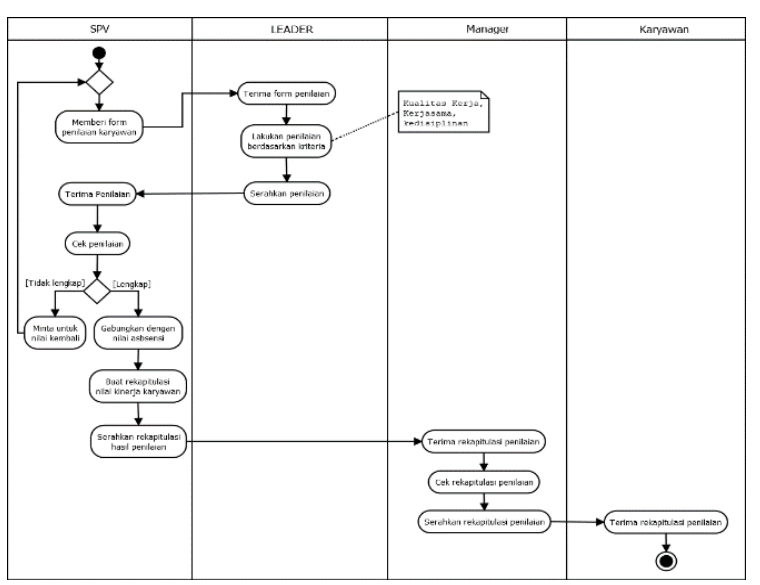

Gambar 2. Activity Diagram Proses Berjalan

\subsection{Analisa Masalah}

Dalam menganalisa permasalahan penulis menggunakan Fishbone Diagram untuk menganalisa masalah perangkingan penilaian untuk menentukan karyawan terbaik pada PT. Armorindo Artha pada Gambar 4.

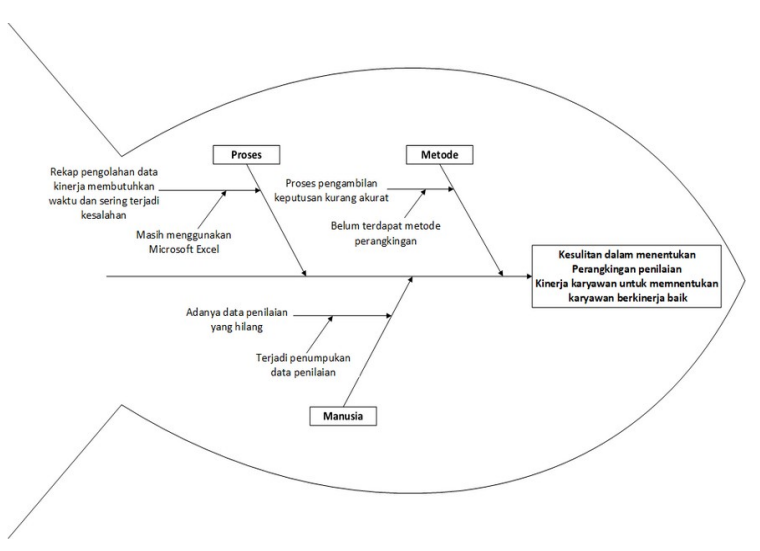

Gambar 3. Fishbone Diagram

Tabel 2. Faktor dan Masalah Fishbone Diagram

\begin{tabular}{|c|l|}
\hline Faktor & \multicolumn{1}{|c|}{ Masalah } \\
\hline Manusia & $\begin{array}{l}\text { Mengakibatkan beberapa data } \\
\text { penilaian yang hilang karena } \\
\text { terjadinya penumpukan data penilaian } \\
\text { kinerja. }\end{array}$ \\
\hline Proses & $\begin{array}{l}\text { Mengakibatkan rekap pengolahan data } \\
\text { yang membutuhkan waktu dan sering } \\
\text { terjadi kesalahan karena masih } \\
\text { menggunakan Microsoft excel. }\end{array}$ \\
\hline Metode & $\begin{array}{l}\text { Mengakibatkan hasil pengambilan } \\
\text { keputusan karyawan terbaik kurang } \\
\text { akurat yang disebabkan oleh tidak } \\
\text { adanya metode untuk perangkingan. }\end{array}$ \\
\hline
\end{tabular}

\subsection{Model Keputusan Dengan Metode Simple Additive Weighting (SAW)}

a. Identifikasi Objek

Dalam mengidentifikasi objek pada Metode Simple Additive Weighting (SAW) dilakukan untuk menghitung nilai akhir alternatif yaitu menetapkan karyawan yang terbaik. Hasil yang akan dikeluarkan nanti ialah rangking alternatif yang dimulai dari nilai terbesar hingga alternatif dengan nilai terkecil. Alternatif yang dimaksud adalah karyawan yang bekerja di PT. ARMORINDO ARTHA. Kriteria yang dipakai dalam penetapan karyawan terbaik dalam atribut profit (benefit) yang terdiri dari 4 kriteria, yaitu Absen, Kualitas Kerja, Kerjasama, dan Kedisiplinan. Setiap kriteria mempunyai bobot, hasil perhitungan matriks antar alternatif dengan kriteria memakai metode Simple Additive Weighting (SAW) akan memperoleh karyawan yang memiliki kinerja baik untuk menjadi karyawan terbaik.

b. Identifikasi Kriteria

1) Identifikasi Kriteria

Tabel 3 di bawah ini merupakan kriteria yang diperlukan pada saat menentukan keputusan karyawan terbaik pada PT. ARMORINDO ARTHA.

Tabel 3. Ketentuan Kriteria Kode Kriteria $\quad$ Nama Kriteria

\begin{tabular}{|c|c|}
\hline 1 & Absensi \\
\hline 2 & Kulitas Kerja \\
\hline 3 & Kerjasama \\
\hline 4 & Kedisiplinan \\
\hline
\end{tabular}

2) Bobot Kriteria

Berdasarkan data yang ada, Tabel 4 berikut ini ialah nilai persentasi bobot kriteria yang terdapat serta ditetapkan oleh Supervisor berdasarkan kriteria yang telah ditentukan di atas. Total bobot jika dijumlahkan tidak boleh lebih dari 100\%.

Tabel 4. Persentase Bobot Kriteria

\begin{tabular}{|c|c|c|}
\hline Kode Kriteria & Nama Kriteria & Bobot \\
\hline 1 & Absensi & $20 \%$ \\
\hline 2 & Kulitas Kerja & $30 \%$ \\
\hline 3 & Kerjasama & $30 \%$ \\
\hline 4 & Kedisiplinan & $20 \%$ \\
\hline \multicolumn{2}{|c|}{ Total } & $100 \%$ \\
\hline
\end{tabular}

c. Identifikasi Alternatif 
Berdasarkan banyaknya Karyawan pada PT. ARMORINDO ARTHA, maka diambil 5 (lima) karyawan sebagai contoh untuk penerapan dengan metode Simple Additive Weighting (SAW) dalam menentukan karyawan terbaik. Dimana data merupakan hasil rekapitulasi penilaian dari setiap kriteria yang ditampilkaan di Tabel 5 berikut.

Tabel 5. Nilai Alternatif Per Kriteria

\begin{tabular}{|l|c|c|c|c|}
\hline Alternatif & Absen & $\begin{array}{c}\text { Kulaitas } \\
\text { Kerja }\end{array}$ & $\begin{array}{c}\text { Kerjasa } \\
\text { ma }\end{array}$ & $\begin{array}{c}\text { Kedisipl } \\
\text { inan }\end{array}$ \\
\hline $\begin{array}{l}\text { Ali } \\
\text { Sadewo }\end{array}$ & 95 & 85 & 87 & 85 \\
\hline $\begin{array}{l}\text { Budi } \\
\text { Wijaya } \\
\text { Kusuma }\end{array}$ & 95 & 80 & 75 & 87 \\
\hline $\begin{array}{l}\text { M.Eggy } \\
\text { Hidayat }\end{array}$ & 93 & 82 & 85 & 90 \\
\hline $\begin{array}{l}\text { Rifki } \\
\text { Fauzi }\end{array}$ & 90 & 80 & 80 & 85 \\
\hline $\begin{array}{l}\text { Daffa } \\
\text { fadillah }\end{array}$ & 100 & 75 & 70 & 90 \\
\hline
\end{tabular}

- Nilai absen dimasukkan dari nilai persentase hasil absensi.

- Nilai kualitas kerja, kerjasama dan kedisplinan dimasukkan dari hasil nilai karyawan per kriteria.

\subsection{Pengolahan Data}

Pertama dilakukan normalisasi menjadi matriks untuk menghitung nilai masing-masing kriteria, menghitung berdasarkan kriteria keuntungan atau kriteria biaya dengan persamaan sebagai berikut:

Keterangan :

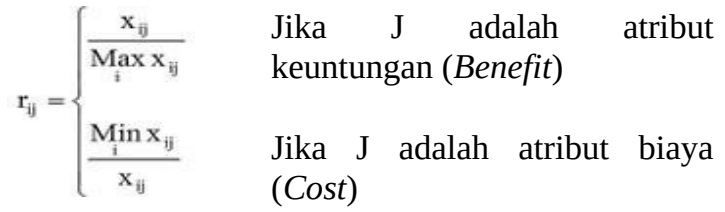

$$
\begin{aligned}
& \text { Rij }=\text { nilai rating kinerja ternormalisasi. } \\
& \text { Xij }=\text { nilai atribut yang didapat dari } \\
& \text { setiap kriteria. } \\
& \text { Max Xij = nilai terbesar alternatif dari setiap } \\
& \text { kriteria i. }
\end{aligned}
$$

Tabel 6. Penggolongan Kriteria

\begin{tabular}{|c|c|c|c|}
\hline \multirow{2}{*}{ No } & \multirow{2}{*}{ Kriteria } & \multicolumn{2}{|c|}{ Tipe Kriteria } \\
\cline { 3 - 4 } & & Benefit & Cost \\
\hline 1 & Absen & $\forall$ & \\
\hline 2 & Kualitas Kerja & $\forall$ & \\
\hline 3 & Kerjasama & $\forall$ & \\
\hline 4 & Kedisiplinan & $\forall$ & \\
\hline
\end{tabular}

Berikut adalah perhitungan tiap kriteria sehingga didapatkan nilai dari tiap alternatif.

a. Perhitungan Kriteria Absensi

$$
\begin{aligned}
& R 1=\frac{95}{\max (95 ; 95 ; 93 ; 90 ; 100)}=\frac{95}{100}=0.95 \\
& R 21=\frac{95}{\max (95 ; 95 ; 93 ; 90 ; 100)}=\frac{95}{100}=0.95 \\
& R 31=\frac{93}{\max (95 ; 95 ; 93 ; 90 ; 100)}=\frac{93}{100}=0.93 \\
& R 41=\frac{90}{\max (95 ; 95 ; 93 ; 90 ; 100)}=\frac{90}{100}=0.9 \\
& R 51=\frac{100}{\max (95 ; 95 ; 93 ; 90 ; 100)}=\frac{100}{100}=1
\end{aligned}
$$

b. Perhitungan Kriteria Kualitas Kerja

$$
\begin{aligned}
& R 12=\frac{85}{\max (85 ; 80 ; 82 ; 80 ; 75)}=\frac{85}{85}=1 \\
& R 22=\frac{80}{\max (85 ; 80 ; 82 ; 80 ; 75)}=\frac{80}{85}=0.941 \\
& R 32=\frac{82}{\max (85 ; 80 ; 82 ; 80 ; 75)}=\frac{82}{85}=0.964 \\
& R 42=\frac{80}{\max (85 ; 80 ; 82 ; 80 ; 75)}=\frac{80}{85}=0.941 \\
& R 52=\frac{75}{\max (85 ; 80 ; 82 ; 80 ; 75)}=\frac{75}{85}=0.882
\end{aligned}
$$

c. Perhitungan Kriteria Kerjasama

$$
\begin{aligned}
& R 13=\frac{87}{\max (87 ; 75 ; 85 ; 80 ; 70)}=\frac{87}{87}=1 \\
& R 23=\frac{75}{\max (87 ; 75 ; 85 ; 80 ; 70)}=\frac{75}{87}=0.862 \\
& R 33=\frac{85}{\max (87 ; 75 ; 85 ; 80 ; 70)}=\frac{85}{87}=0.977 \\
& R 43=\frac{80}{\max (87 ; 75 ; 85 ; 80 ; 70)}=\frac{80}{87}=0.919 \\
& R 53=\frac{70}{\max (87 ; 75 ; 85 ; 80 ; 70)}=\frac{70}{87}=0.804
\end{aligned}
$$

d. Perhitungan Kriteria Kedisplinan

$$
\begin{aligned}
& R 14=\frac{85}{\max (85 ; 87 ; 90 ; 85 ; 90)}=\frac{85}{90}=0.944 \\
& R 24=\frac{87}{\max (85 ; 87 ; 90 ; 85 ; 90)}=\frac{87}{90}=0.966 \\
& R 34=\frac{90}{\max (85 ; 87 ; 90 ; 85 ; 90)}=\frac{90}{90}=1 \\
& R 44=\frac{85}{\max (85 ; 87 ; 90 ; 85 ; 90)}=\frac{85}{90}=0.944 \\
& R 54=\frac{90}{\max (85 ; 87 ; 90 ; 85 ; 90)}=\frac{90}{90}=1
\end{aligned}
$$

\subsection{Hasil Penelitian}

Kemudian dari bobot yang telah ditentukan sebelumnya dihitung untuk mendapatkan alternatif yang terbaik. 
Tabel 7. Matriks Normalisasi

\begin{tabular}{|l|c|c|c|c|}
\hline Alternatif & $\begin{array}{c}\text { Abse } \\
\text { nsi }\end{array}$ & $\begin{array}{c}\text { Kualitas } \\
\text { Kerja }\end{array}$ & $\begin{array}{c}\text { Kerjas } \\
\text { ama }\end{array}$ & $\begin{array}{c}\text { Kedisi } \\
\text { plinan }\end{array}$ \\
\hline Ali Sadewo & 0.95 & 1 & 1 & 0.944 \\
\hline $\begin{array}{l}\text { Budi Wijaya } \\
\text { Kusuma }\end{array}$ & 0.95 & 0.941 & 0.862 & 0.966 \\
\hline $\begin{array}{l}\text { M.Eggy } \\
\text { Hidayat }\end{array}$ & 0.93 & 0.964 & 0.977 & 1 \\
\hline Rifki Fauzi & 0.9 & 0.941 & 0.919 & 0.944 \\
\hline $\begin{array}{l}\text { Daffa } \\
\text { fadillah }\end{array}$ & 1 & 0.882 & 0.804 & 1 \\
\hline Bobot & $\mathbf{0 . 2}$ & $\mathbf{0 . 3}$ & $\mathbf{0 . 3}$ & $\mathbf{0 . 2}$ \\
\hline
\end{tabular}

Tahap berikutnya adalah proses nilai preferensi untuk setiap karyawan dengan persamaan berikut ini:

$$
\mathrm{V}_{\mathrm{i}}=\sum_{\mathrm{j}=1}^{\mathrm{n}} \mathrm{w}_{\mathrm{j}} \mathrm{r}_{\mathrm{ij}}
$$

$\mathrm{Vi}=$ Hasil untuk setiap alternatif

wj = Angka dari bobot per kriteria

rij = Angka dari rating kinerja ternormalisasi

\section{1) Ali Sadewo}

$$
\begin{aligned}
& =(0.2 \times 0.95)+(0.3 \times 1)+(0.3 \times 1)+(0.2 \times 0.944) \\
& =(0.19+0.3+0.3+0.1888) \\
& =0.9788
\end{aligned}
$$

2) Budi Wijaya Kusuma

$$
\begin{aligned}
& =\{(0.2 \times 0.95)+(0.3 \times 0.941)+(0.3 \times 0.862)+(0.2 \times 0.966)\} \\
& =(0.19+0.2823+0.2586+0.1932) \\
& =0.9241
\end{aligned}
$$

3) M.Eggy Hidayat

$$
\begin{aligned}
& =\{(0.2 \times 0.93)+(0.3 \times 0.964)+(0.3 \times 0.977)+(0.2 \times 0.1)\} \\
& =(0.186+0.2892+0.2931+0.2) \\
& =0.9683
\end{aligned}
$$

4) Rifki Fauzi

$$
\begin{aligned}
& =\{(0.2 \times 0.9)+(0.3 \times 0.941)+(0.3 \times 0.919)+(0.2 \times 0.944)\} \\
& =(0.81+0.2823+0.2757+0.1888) \\
& =0.9268
\end{aligned}
$$

5) Daffa Fadillah

$$
\begin{aligned}
& =\{(0.2 \times 1)+(0.3 \times 0.882)+(0.3 \times 0.804)+(0.2 \times 1)\} \\
& =(0.2+0.2646+0.2412+0.2) \\
& =0.9058
\end{aligned}
$$

Dari hasil perhitungan diatas di dapatkan hasil sebagai berikut:

$$
\begin{aligned}
& \text { Rangking } 1 \text { : Ali Sadewo } \\
& \text { Rangking } 2 \text { : M.Eggy Hidayat } \\
& \text { Rangking } 3 \text { : Rifki Fauzi } \\
& \text { Rangking } 4 \text { : Budi Wijaya Kusuma } \\
& \text { Rangking } 5 \text { : Daffa Fadillah }
\end{aligned}
$$

Sehingga dapat disimpulkan bahwa nilai terbesar diperoleh oleh Ali Sadewo sebagai alternatif terbaik dengan nilai 0.9788

\subsection{Identifikasi Kebutuhan}

Hasil analisa yang didapat dalam bentuk uraian masalah yang akan dikaitkan dengan pengolahan data kriteria, data karyawan, kebutuhan sistem penunjang keputusan pada perbaikan yang diharapkan. Semua hal yang berhubungan dengan keperluan yang dijabarkan ialah keperluan sistem yang ingin dicapai.

a. Use Case Diagram Input

Pada use case diagram input supervisor menjadi actor serta ada 2 use case yaitu entry data karyawan dan entry data kriteria yang terdapat pada Gambar 4.

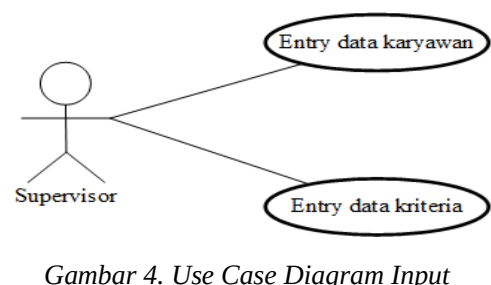

b. Use Case Diagram Proses

Pada use case diagram proses supervisor menjadi actor serta ada 4 use case yaitu entry data absensi karyawan, entry data nilai karyawan per kriteria, tampil hasil normalisasi, dan entry hasil keputusan yang terdapat di Gambar 5.

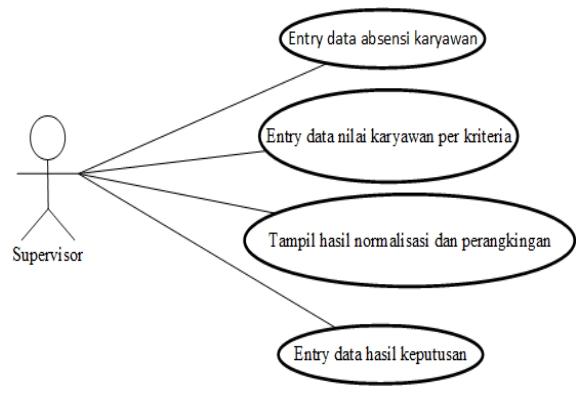

Gambar 5. Use Case Diagram Proses

\section{c. Use Case Diagram Laporan}

Pada use case diagram laporan supervisor dan manager menjadi actor serta ada 3 use case yaitu cetak laporan nilai karyawan, cetak laporan rangking karyawan dan cetak laporan karyawan terbaik yang terdapat pada Gambar 6.

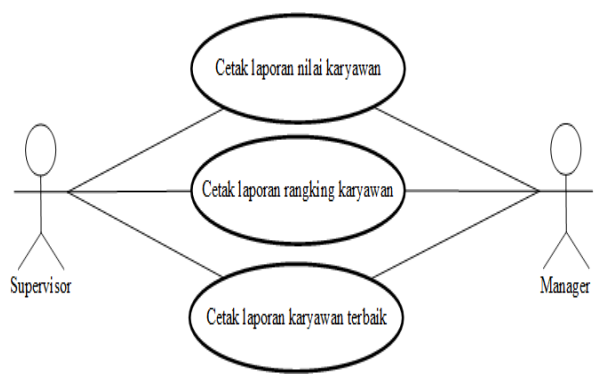

Gambar 6. Use Case Diagram Laporan 


\subsection{Entity Relationship Diagram (ERD)}

Berikut rancangan basis data yang akan digambarkan dalam bentuk ERD ada beberapa entitas yang digunakan yaitu absen, karyawan, kriteria dan hasil, kemudia terciptanya entitas baru yaitu punya. Berikut rancangan ERD yang terdapat pada Gambar 7.

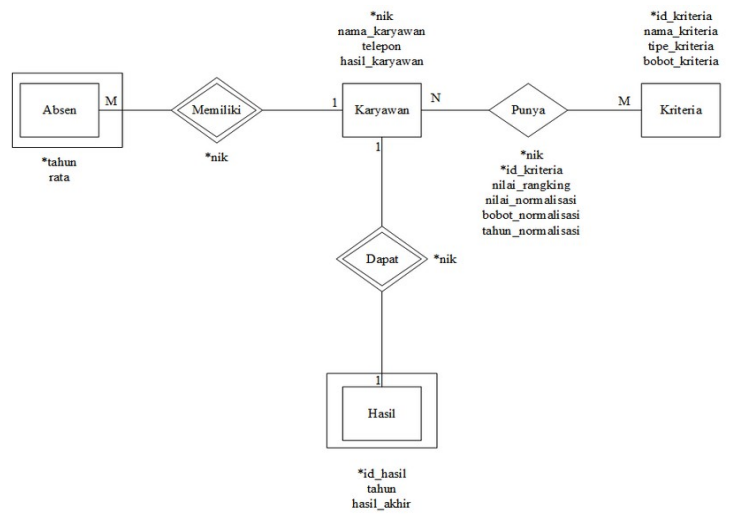

Gambar 7. Entity Relationship Diagram (ERD)

\subsection{Struktur Tampilan Menu}

Berikut adalah struktur tampilan menu yang terdapat pada sistem yang dibuat yaitu ada input, proses, dan laporan. Akan ditampilkan pada Gambar 8.

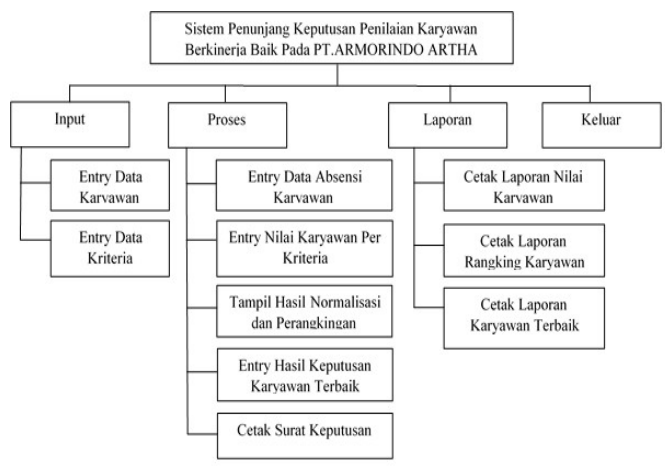

Gambar 8. Struktur Tampilan Menu

\subsection{Rancangan Layar}

a. Tampilan Layar Data Karyawan

Rancangan layar data karyawan ini untuk mengetahui data karyawan yang akan ditampilkan di Gambar 9.

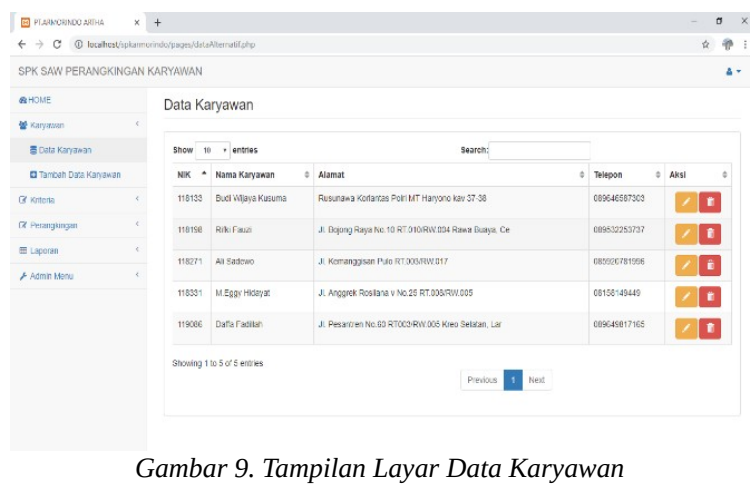

b. Tampilan Layar Absensi Karyawan

Rancangan layar absensi ini untuk menginput nilai absensi per karyawan yang akan ditampilkan pada Gambar 10.

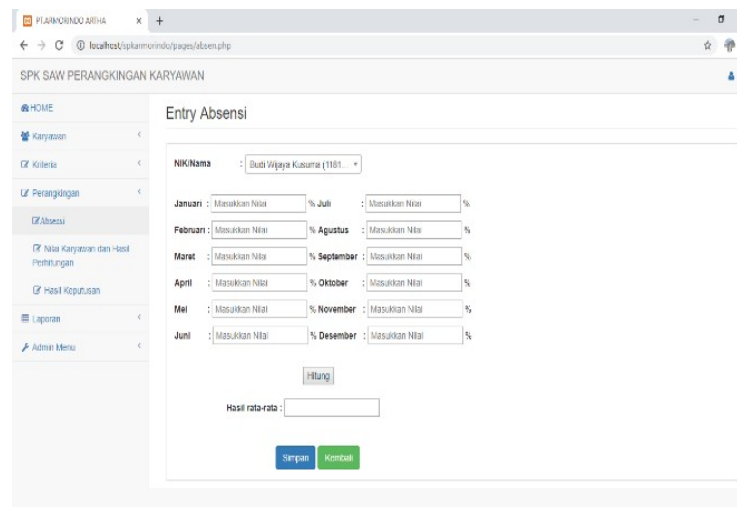

Gambar 10. Tampilan Layar Absensi Karyawan

c. Tampilan Layar Nilai Karyawan Per Kriteria Rancangan layar nilai karyawan per kriteria ini untuk menampilkan hasil nilai karyawan per kriteria yang akan ditampilkan pada Gambar 11.

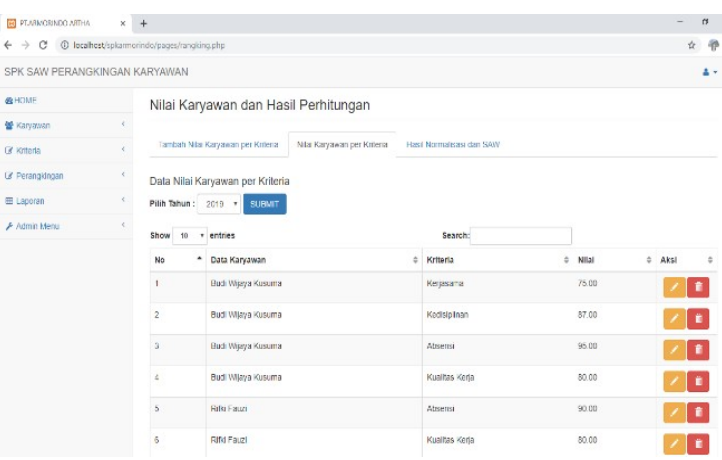

Gambar 11. Tampilan Layar Nilai Karyawan Per Kriteria

d. Tampilan Layar Hasil Normalisasi dan Perangkingan

Rancangan layar hasil normalisasi dan perangkingan untuk menampilkan hasil matriks normalisasi dan hasil SAW yang akan ditampilkan pada Gambar 12. 


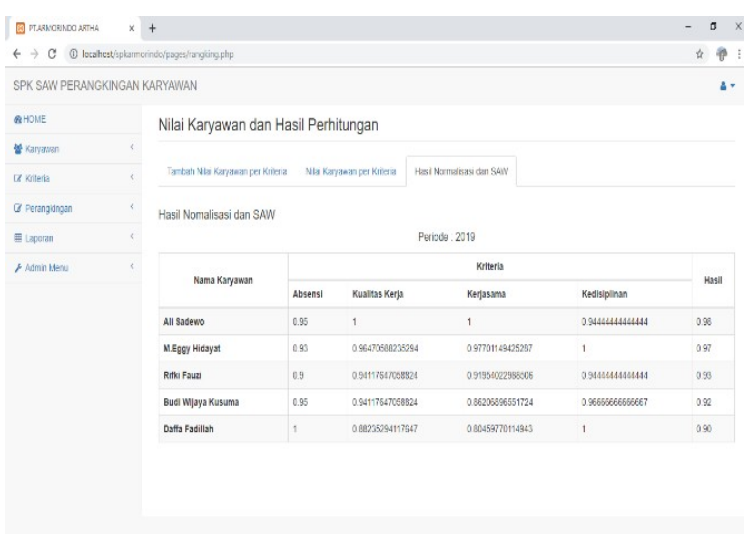

Gambar 12. Tampilan Layar Hasil Normalisasi dan Perangkingan

e. Tampilan Layar Hasil Keputusan Karyawan Terbaik

Rancangan layar hasil keputusan ini untuk memilih calon karyawan terbaik yang akan ditampilkan pada Gambar 13.

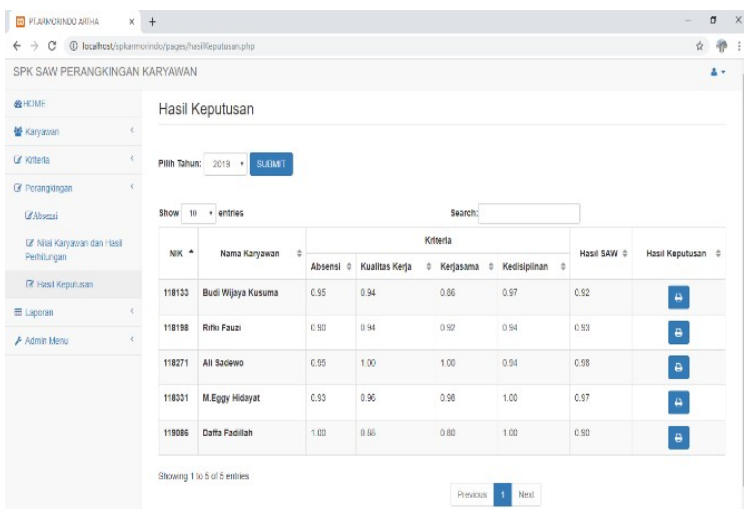

Gambar 13. Tampilan Layar Hasil Keputusan Karyawan Terbaik

\section{KESIMPULAN}

Berdasarkan penelitian yang telah diterapkan dapat disimpulkan beberapa hal berikut ini:

a. Setelah terbuatnya sistem penunjang keputusan, diharapkan dapat mempermudah Supervisor PT. Armorindo Artha dalam menentukan Karyawan yang berkinerja baik

b. Dipakainya metode Simple Additive Weighting (SAW) dapat memproses perhitungan nilai karyawan sesuai kriteria yang sudah ditetapkan sebelumnya, sehingga menghasilkan nilai akhir yang dapat digunakan Supervisor selaku pengambil keputusan dalam memilih Karyawan terbaik. c. Sistem penunjang keputusan dapat digunakan untuk mempercepat proses pengambilan keputusan.

d. Supervisor akan lebih mudah melakukan pemilihan calon karyawan terbaik meskipun terdapat hasil penilaian yang sama. Supervisor tidak perlu lagi mencari dan melihat data calon karyawan lalu membandingkannya satu persatu karena semua data sudah tersimpan ke dalam sistem.

Adapun saran mengenai Sistem Penunjang Keputusan Penentuan Karyawan Terbaik pada PT.Armorindo Artha berikut ini ialah :

a. Setelah terbuatnya sistem penunjang keputusan harus memerlukan ketelitian pada saat menginput data sehingga menghasilkan keputusan yang tepat, akurat, dan hasil maksimal.

b. Ketika user ingin menggunakan sistem penunjang keputusan harus membutuhkan pelatihan agar sistem dapat dijalankan dengan baik dan benar.

c. Diharapkan sistem penunjang keputusan ini dapat di integrasikan dengan sistem lainnya yang terdapat pada PT. ARMORINDO ARTHA.

\section{DAFTAR PUSTAKA}

[1] E. Turban, J. E. Aronson, And T.-P. Liang, "Decision Support Systems And Business Intelligence,” Decis. Support Bus. Intell. Syst. 7/E, Pp. 1-35, 2007.

[2] P. Setiaji, "Sistem Pendukung Keputusan Dengan Metode Simple Additive Weighting," Simetris J. Tek. Mesin, Elektro Dan Ilmu Komput., Vol. 1, No. 1, P. 59, 2013.

[3] N. Chafid And N. Harianto, "Sistem Pendukung Keputusan Penilaian Karyawan Grade Terbaik Dengan Metode Simple Additive Weighthing ( Saw ),” Pros. Semin. Nas. Inov. Teknol., Pp. 131140, 2017.

[4] A. G. Anto, H. Mustafidah, And A. Suyadi, "Sistem Pendukung Keputusan Penilaian Kinerja Karyawan Menggunakan Metode Saw ( Simple Additive Weighting )," Juita, Vol. Iii, No. November, Pp. 193-200, 2015.

[5] H. Murdianto, D. M. Khairina, And H. R. Hatta, "Sistem Pendukung Keputusan Pemilihan Karyawan Terbaik Per Triwulan Pt.Cahaya Fajar Kaltim Pltu Embalut Tanjung Batu Menggunakan Metode Simple Additive Weighting," Pros. Semin. Ilmu Komput. Dan Teknol. Inf. , Vol. 1, No. 1, Pp. 24-29, 2016. 